\title{
PENDAMPINGAN PEMANFAATAN \\ BUAH-BUAHAN LOKAL DAN PELEPAH PISANG BERBASIS WORKING WITH COMMUNITY
}

\author{
Komariyati $^{1 *}$, Widadi Padmarsari Soetignya ${ }^{2}$, Renny Anggraini ${ }^{3}$ \\ ${ }^{1}$ Program Studi Agribisnis, Universitas Tanjungpura, Pontianak, Indonesia \\ ${ }^{2}$ Program Studi Manajemen Sumberdaya Perairan, Universitas Tanjungpura, Pontianak, Indonesia \\ ${ }^{3}$ Politeknik Tonggak Equator, Pontianak, Indonesia \\ "Penulis Korespondensi: komariyati0406@gmail.com
}

\begin{abstract}
Abstrak
Desa Lingga adalah daerah lintas negara yang memiliki sumber daya buah-buahan lokal, tetapi belum ada diversifikasi olahan sehingga saat panen raya, harga menurun dan banyak produk yang tidak terserap pasar. Program Kuliah Kerja Nyata - Pembelajaran Pemberdayaan Masyarakat (KKN-PPM) ini merupakan upaya Pemberdayaan Ibu Rumah Tangga dalam Peningkatan Nilai Tambah Buahbuahan Lokal melalui Diversifikasi Olahan dan Produk Kerajinan di Desa Lingga Kecamatan Sungai Ambawang. Target program ini meliputi : (1). Terciptanya kerjasama yang sinergi antara Perguruan Tinggi dan masyarakat pedesaan dalam bentuk Kuliah Kerja Nyata - Pembelajaran Pemberdayaan Masyarakat, (2) Meningkatkan kepedulian dan empati para mahasiswa kepada permasalahan masyarakat pedesaan khususnya masyarakat ekonomi menengah ke bawah, sehingga terjadi perubahan pola pikir dan perilaku mahasiswa dan kelompok sasaran, (3). Mengatasi permasalahan terutama dalam peningkatan pendapatan ekonomi menengah ke bawah dengan memaksimumkan pemberdayaan masyarakat desa khususnya untuk ibu rumah tangga. Metode yang digunakan dalam program KKN-PPM adalah metode pemberdayaan masyarakat melalui pelatihan dan pendampingan divesifikasi buah-buahan lokal dan produk kerajinan pelepah pisang dengan konsep working with community. Kegiatan-kegiatan mahasiswa KKN-PPM yang telah dilaksanakan adalah sosialisasi, peningkatan kompetensi ibu-ibu rumah tangga dalam produksi olahan buah-buahan lokal dan kerajinan tangan dari pelepah pisang melalui pelatihan dan pendampingan dengan peningkatan partisipasi ibu-ibu rumah tangga.
\end{abstract}

Kata Kunci: Buah-buahan Lokal, Diversifikasi Olahan, Nilai Tambah, Produk Kerajinan

\begin{abstract}
Lingga village is a cross-country area that has lokal fruit resources, but there is no processed diversification so that during the harvest, prices decline and many products are not absorbed by the market. This KKN-PPM program is an effort to Empower Housewives in Increasing the Added Value of Lokal Fruits through Processed Diversification and Craft Products in Lingga Village, Sungai Ambawang District. This activity is an effort to process bananas and rambutan into banana salads and jam, sweets of rambutan and handicraft products from banana midrib waste. The program targets include: (1). The creation of synergy cooperation between Universities and rural communities in the form of Student Study Services - Community Empowerment Learning, (2) Increasing the care and empathy of students to the problems of rural communities, especially the middle to lower economic communities, so that there is a change in mindset and behavior of students and target groups, (3). Overcoming the problems, especially in increasing the income of the middle to lower economy by maximizing the empowerment of rural communities, especially for housewives. The method used in the $K K N-P P M$ program is a method of empowering the community through training and mentoring diversification of lokal fruits and banana midrib handicraft products with the concept of working with community. KKN-PPM student activities that have been carried out are socialization, improving the competence of housewives in the production of lokally processed fruits and handicrafts from banana midribs through training and mentoring with increased participation of housewives.
\end{abstract}

Keywords: Local fruits, processed diversification, added value, handicraft products 


\section{PENDAHULUAN}

Desa Lingga merupakan salah satu desa yang terletak di Kecamatan Sungai Ambawang yang secara tepat berada di daerah yang dilalui oleh jalan propinsi yang merupakan jalan lintas antar negara menuju Serawak Malaysia. Perlintasan jalan raya ini membuat daerah yang dulunya hanya berupa hutan selama beberapa tahun terakhir menjadi kawasan yang terbuka untuk pengembangan ekonomi. Namun demikian belum diimbangi dengan kemajuan masyarakat baik kemajuan wawasan, teknologi dan kesejahteraan sehingga belum siap dalam menghadapi perkembangan ini. Terbukti di Kecamatan Sungai Ambawang terdapat 1.645 Kepala Keluarga (KK) yang termasuk kelompok pra sejahtera dari total 14.142 KK dan yang termasuk keluarga miskin sebesar 34.15\% (Badan Pemberdayaan Perempuan dan Keluarga Berencana Kabupaten Kubu Raya, 2011). Hal tersebut senada dengan yang diinformasikan oleh Tim Nasional Percepatan Penanggulangan Kemiskinan (TNP2K) Provinsi Kalimantan Barat bahwa keluarga miskin di Kecamatan Sungai Ambawang sebanyak 3.958 KK dari 29.247 KK di Kubu Raya atau 22.207 jiwa dari 154.634 jiwa di Kabupaten Kubu Raya (Anonim, 2012). Menurut Kepala Desa Lingga, jumlah KK miskin sebanyak $255 \mathrm{KK}$ pada tahun 2016 dan masih merupakan daerah rawan pangan. Kurang siapnya masyarakat Desa Lingga menghadapi perkembangan ditunjukkan juga dengan masih rendahnya tingkat pendidikan, dimana persentase tingkat pendidikan SD dan tidak lulus SD masih mendominasi tingkat pendidikan penduduk di Desa Lingga, yaitu 48 persen, bahkan terdapat 110 jiwa yang masih buta huruf (Anonim, 2016).

Dewi (2015), mengatakan pendampingan di Desa Lingga dengan membentuk Kawasan Ekonomi Masyarakat merupakan salah satu cara untuk difusi teknologi tepat guna sehingga mampu meningkatkan pendapatan dan pseudo IPM. Demikian juga dengan Program Iptek bagi Masyarakat melalui olahan pisang dan limbahnya telah meningkatkan pendapatan keluarga (Pramulya, 2016). Namun demikian ketahanan pangan rumah tangga belum tercapai karena program ini masih terpusat di pusat Desa Lingga, yaitu Dusun Lingga Timur.

Di satu sisi Kecamatan Sungai Ambawang termasuk Desa Lingga terdapat berbagai buah-buahan lokal yang dapat dimanfaatkan untuk mengatasi kerawanan pangan. Gambaran jumlah produksi komoditi primadona di Kabupaten Kubu Raya tahun 2013 terlihat pada tabel berikut.
Tabel 1. Jenis dan Produksi Komoditi Primadona Kabupaten Kubu Raya Tahun 2013

\begin{tabular}{clr}
\hline No. & Jenis Komoditi & Produksi (ton) \\
\hline 1 & Nanas & $44.612,2$ \\
2 & Pisang & $6.686,2$ \\
3 & Pepaya & $3.228,7$ \\
4 & Durian & $1.179,6$ \\
5 & Rambutan & 662,7 \\
6 & Nangka/cempedak & 590,9 \\
7 & Duku/langsat & 502,1 \\
\hline
\end{tabular}

Sumber : BPS Kubu Raya, 2014

Komoditas hortikultura dari kelompok buah - buahan yang saat ini perlu mendapat perhatian adalah pisang dan rambutan. Ke 2 (dua) jenis buah-buahan ini selalu ada di tiap lahan pekarangan rumah penduduk di Desa Lingga, tetapi hampir tidak ada pemeliharaan atau perawatan khusus yang dilakukan oleh masyarakat desa terkait dengan buah-buahan lokal ini. Hasil panen lebih dikonsumsi sendiri dalam bentuk buah segar atau kalaupun dijual masih sebatas di depan rumah sendiri, sehingga pasar masih sangat terbatas.

Berbagai permasalahan dan kendala dalam pengembangan ke 2 (dua) jenis buah-buahan lokal di Desa Lingga. Untuk tanaman pisang, teknologi yang dimiliki petani masih mengandalkan intuisi semata yang dilakukan secara turun temurun dan menjual hasil panen secara langsung (bentuk mentah). Sementara, salah satu karakteristik produk pertanian, termasuk pisang memiliki sifat mudah rusak (perishable) sehingga diperlukan pengolahan lebih lanjut. Demikian halnya buah rambutan. Pada saat panen raya, hampir bisa dikatakan hasil panen ini sangat rendah harganya, bahkan masyarakat mengatakan tidak laku dijual sehingga terbuang dengan sia-sia.

Tanaman buah-buahan termasuk pisang dan rambutan merupakan tanaman dengan masa simpan yang sangat singkat, sehingga diperlukan alternatif pengolahan pasca panen untuk meningkatkan nilai tambah. Buahbuah lokal ini bisa menjadi sumber pangan yang sehat dan tentunya menjadi tambahan income bagi ibu-ibu rumah tangga yang akhirnya meningkatkan pendapatan/kesejahteraan keluarga jika ibu-ibu mampu menerapkan teknologi pengolahannya, yang pada akhirnya situasi rawan pangan di Desa Lingga dapat diatasi. Program Kuliah Kerja Nyata Pemberdayaan dan Pembelajaran Masyarakat Universitas Tanjungpura (KKN-PPM Untan) merupakan upaya dalam mewujudkan optimalisasi buah-buahan lokal dan limbah pelepah pisang menjadi berbagai olahan pangan dan produk kerajinan yang memiliki nilai ekonomi tinggi.

\section{METODE}

KKN-PPM ini dilaksanakan pada bulan Juli - Agustus 2018 di Desa Lingga, tepatnya di Dusun Lingga Dalam dengan menempatkan 30 orang mahasiswa 
Fakultas MIPA dari berbagai disiplin ilmu/program studi. Metode pelaksanaan kegiatan menggunakan metode pemberdayaan masyarakat melalui pelatihan dan pendampingan dalam difusi ipteks divesifikasi buah-buahan lokal dan produk kerajinan pelepah pisang dengan konsep working with community. Pelaksanaan kegiatan di Desa Lingga didahului dengan persiapan berupa rekruitmen mahasiswa peserta dan pelatihan mahasiswa sebagai pembekalan untuk mahasiswa agar mahasiswa memahami tujuan, konsep serta perannya dalam program KKN-PPM dan siap mengintroduksikan teknologi peningkatan nilai tambah buah-buahan lokal dan pelepah pisang.

Mitra kegiatan ini adalah ibu-ibu rumah tangga di Dusun Lingga Dalam yang berjumlah 174 orang. Diharapkan dengan metode pelaksanaan yang diterapkan dalam program KKN-PPM ini, ada peningkatan nilai tambah buah-buahan lokal dan pelepah pisang yang pada akhirnya akan terjadi peningkatan pendapatan dan kesejahteraan keluarga.

\section{HASIL DAN PEMBAHASAN}

\subsection{Persiapan}

Persiapan perlu dilakukan sebelum mahasiswa peserta KKN-PPM ditempatkan di Desa Lingga. Langkah-langkah persiapan yang telah dilakukan dalam program, sebagai berikut :

a. Orientasi lapangan dalam penetapan Desa Lingga sebagai lokasi KKN-PPM dengan mempertimbangkan potensi yang dimiliki serta kebutuhan masyarakat sasaran.

b. Rekruitmen mahasiswa peserta dalam penetapan peserta KKN-PPM dengan komposisi sesuai bidang keahlian yang dibutuhkan

c. Pembekalan Mahasiswa Peserta KKN-PPM

Pembekalan mahasiswa peserta KKN-PPM, meliputi Materi umum (kebijakan umum program KKN-PPM Untan, tata tertib dan etika, perencanaan program KKN-PPM serta evaluasi dan penyusunan laporan KKN-PPM), dilanjutkan dengan pembekalan materi khusus, yaitu pembuatan produk kerajinan tangan dari pelepah pisang dan diversifikasi buahbuahan lokal beserta analisis ekonomi sebagai dasar manajemen yang baik dari usaha produk kerajinan dan olahan pangan.

Pada orientasi lapangan, tim pelaksana kegiatan program KKN-PPM bertemu dengan tokoh-tokoh masyarakat desa dan dusun (Kepala Desa dan Aparat Desa serta tokoh masyarakat yang lain). Tokoh tokoh masyarakat desa menyambut baik dan siap mendukung kegiatan KKN-PPM ini karena para tokoh desa ini yakin bahwa kegiatan ini akan sangat membantu masyarakat, terutama ibu-ibu rumah tangga dalam meningkatkan ketrampilan dan pendapatan keluarga melalui peningkatan nilai tambah buahbuahan lokal dan pemanfaatan limbah pelepah pisang. Selain program utama, para peserta KKN-PPM dapat membantu dalam bidang pendidikan (membantu mata pelajaran anak-anak SD, baca tulis ibu-ibu rumah tangga, ketrampilan komputer, dan lain-lain) sebagai program tambahan.

Pembekalan terhadap mahasiswa peserta KKN-PPM dilakukan pada hari-hari libur (Sabtu dan Minggu selama 4 hari) dengan metode learning by doing.. Pembekalan dalam pembuatan aneka olahan buahbuahan lokal, yaitu pisang dan rambutan serta pembuatan kerajinan tangan diikuti sangat antusias oleh mahasiswa.

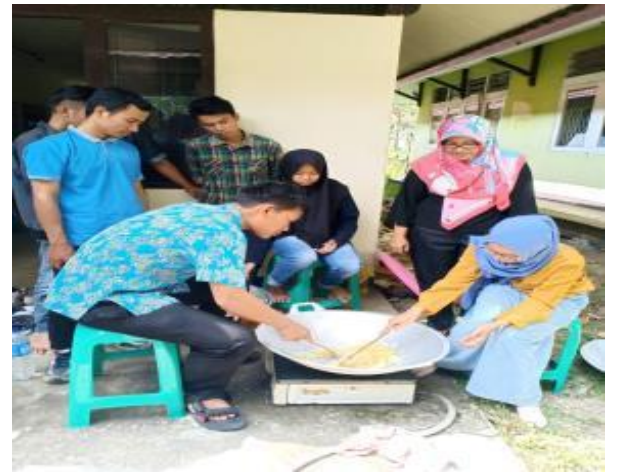

Gambar 1.

Pembekalan Pembuatan Produk Olahan Buah-buahan Lokal

Pembekalan terhadap mahasiswa dalam produksi olahan pisang menjadi salai dan selai pisang serta rambutan menjadi manisan dan selai rambutan diikuti oleh seluruh peserta KKN-PPM. Evaluasi terhadap respon dan kemampuan mahasiswa yang dilakukan melalui tanya jawab dan kuesioner menunjukkan bahwa mahasiswa peserta KKN-PPM telah cukup mampu dalam menguasai materi pembekalan sehingga siap mendampingi ibu-ibu rumah tangga Dusun Lingga Dalam sebagai mitra.

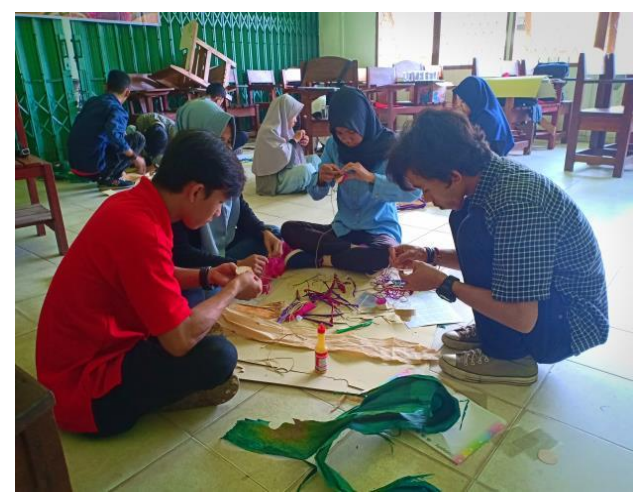

Gambar 2 .

Pembekalan Pembuatan Kerajinan Tangan dari Pelepah Pisang

Materi pembekalan pembuatan produk kerajinan dari pelepah pisang diberikan oleh tim pelaksana KKNPPM, bekerjasama dengan Dinas Perindustrian dan perdagangan provinsi Kalimantan Barat sebagai narasumber, sehingga diharapkan mahasiswa dapat menyerap materi ini secara optimal dan memiliki 
pemahaman serta kemampuan yang cukup memadai dalam melakukan pendampingan terhadap mitra.

\subsection{Pelaksanaan}

Proses pelaksanaan KKN-PPM di Desa Lingga dimulai dengan pembukaan dan penerimaan mahasiswa yang dilakukan di Aula Kantor Camat Sungai Ambawang. Pelaksanaan KKN-PPM secara simbolis dibuka oleh Camat Sungai Ambawang, dihadiri oleh Sekretaris Camat dan 20 (dua puluh) orang pegawai Kantor Kecamatan Sungai Ambawang, staf kepolisian Kecamatan Sungai Ambawang, Kepala Desa Lingga dan perangkatnya serta tokoh masyarakat Dusun Lingga Dalam. Pada intinya Pemerintah Desa Lingga dan Kecamatan Sungai Ambawang menerima dengan senang hati dan siap bekerja sama dengan mahasiswa untuk optimalisasi pemanfaatan buahbuahan lokal dan program tambahan lain, seperti meningkatkan kemampuan masyarakat dalam baca tulis, komputer dan lain-lain.

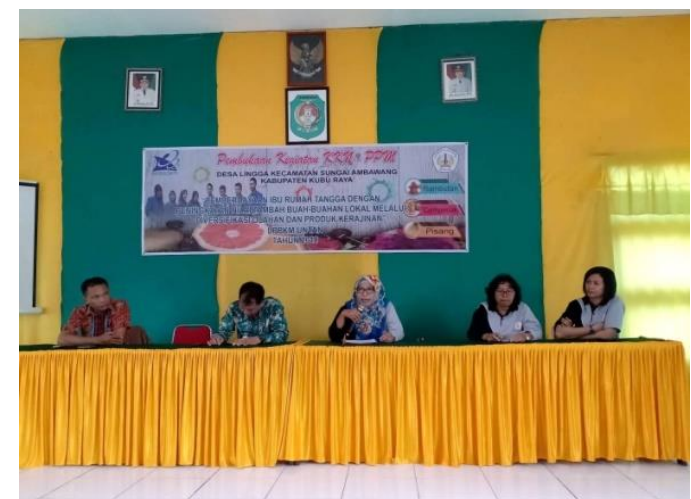

Gambar 3.

Pembukaan Program KKN-PPM Untan Tahun 2018

Pelatihan dan pendampingan pada proses pemberdayaan ibu-ibu rumah tangga dilakukan mahasiswa dengan mengedepankan metode pendidikan orang dewasa, dimana dalam metode ini sangat memprioritaskan adanya keikutsertaan masyarakat/ibu-ibu rumah tangga sasaran. Konsep menggurui dan komunikasi 1 (satu) arah sangat dihindari dalam metode ini. Metode pendidikan ini juga mengedepankan kesetaraan antara mitra dengan mahasiswa pada proses pelatihan dan pendampingan pemanfaatan buah-buahan lokal dan pembuatan produk kerajinan tangan dari pelepah pisang. Dengan metode ini, maka akan terjadi proses "saling belajar" dan kerjasama yang baik antara mahasiswa dengan ibu-ibu rumah tangga Dusun Lingga Dalam.

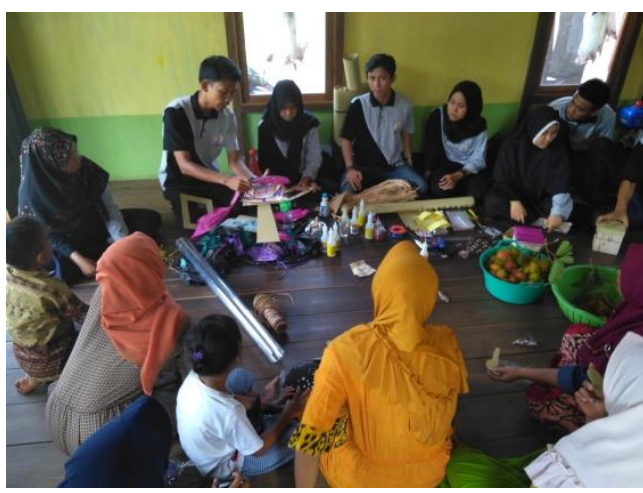

Gambar 4

Pelatihan Pembuatan Produk Kerajinan dari Pelepah Pisang di Dusun Lingga Dalam

Selama ini pemanfaatan pisang oleh masyarakat Dusun Lingga Dalam masih sebatas pada buah segar yang dinikmati langsung. Pohon pisang langsung ditebang setelah dipetik buahnya dan dibiarkan membusuk di sekitar pohon pisang yang belum berproduksi (berbuah) sehingga lingkungan terkesan tidak terawat. Fauziati (2008) menyatakan selain bentuk buah segar, bagian lain yang dapat dimanfaatkan sebagai bahan makanan adalah jantung pisang, bonggol pisang dan yang tidak kalah pentingnya adalah batang pisang yaitu kulit pelepah batang pisang yang digunakan sebagai bahan baku furniture.

Teknologi pembuatan produk kerajinan tangan berupa kotak tissue, figura/bingkai foto, dan berbagai souvenir cantik dari pelepah pisang yang diintroduksikan oleh mahasiswa peserta KKN-PPM kepada ibu-ibu rumah tangga Dusun Lingga Dalam menjadi solusi dalam pemanfaatan pelepah pisang yang selama ini hanya menjadi limbah yang belum termanfaatkan. Pemanfaatan limbah pisang ini, selain memperbaiki kondisi lingkungan juga dapat menjadi solusi dalam meningkatkan efektifitas penggunaan waktu luang oleh ibu-ibu rumah tangga sekaligus dapat meningkatkan pendapatan keluarga.

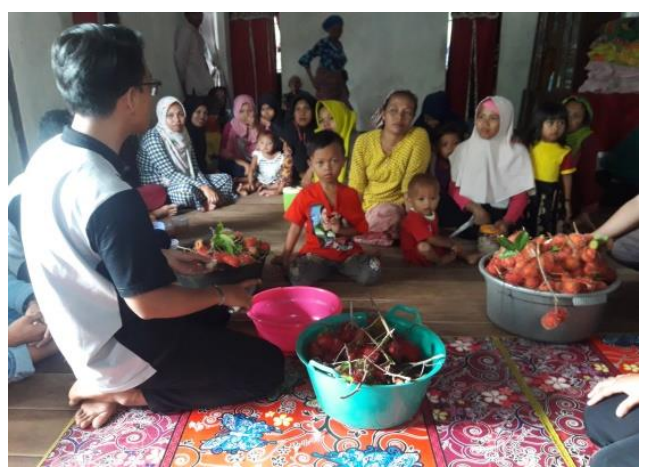

Gambar 5.

Pelatihan Produk Olahan Rambutan di Dusun Lingga Dalam 


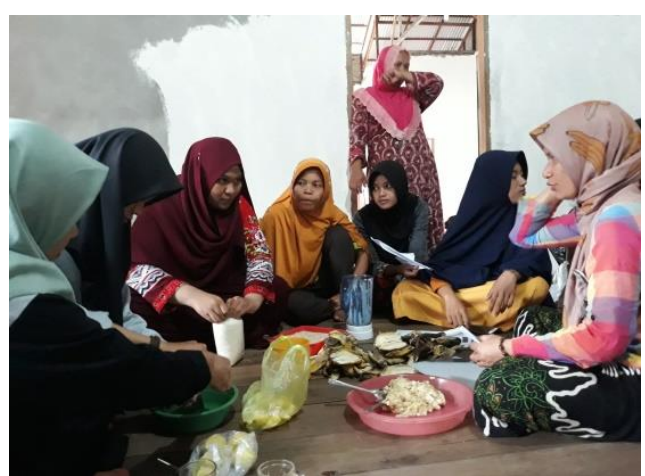

Gambar 6.

Pelatihan Produk Olahan Pisang di Dusun Lingga Dalam

Produksi pisang di Indonesia yang cukup tinggi tidak sebanding dengan tingkat konsumsi masyarakat, sehingga mengakibatkan banyaknya pisang yang tidak dimanfaatkan karena daya simpan buah pisang yang relatif singkat, sehingga solusi terbaik dari masalah ini adalah dengan membuat pisang menjadi produk olahan salai dan tepung (Putri, dkk., 2015). Upaya pengolahan pisang menjadi selai dan salai pisang merupakan bentuk olahan yang diintroduksikan oleh mahasiswa KKN-PPM Untan yang didampingi oleh Dosen Pembimbing Lapangan (DPL). Salai pisang adalah makanan semi basah dibuat dari pisang matang dengan cara pengeringan dan atau pengasapan dengan atau tanpa penambahan pengawet (Prabawati, dkk., 2008)

Pohon rambutan termasuk salah satu jenis tanaman buah tropis yang sangat cocok dikembangkan di Indonesia dan mempunyai nilai ekonomi cukup bagus (Widyawati, dkk, 2016). Pemanfaatan buah rambutan yang diolah menjadi selai dan manisan rambutan bisa meningkatkan nilai tambah buah rambutan di Dusun Lingga Dalam. Selama ini buah rambutan hampir tidak memiliki nilai pada saat musim panen sehingga sering sekali buah rambutan dibiarkan begitu saja di pohon dan jatuh dengan sendirinya. Diharapkan olahan buah rambutan berupa manisan dan selai rambutan dapat menjadi solusi dalam meningkatkan nilai tambah buah lokal rambutan yang akhirnya dapat meningkatklan pendapatan keluarga.

Pelatihan dan pendampingan analisis ekonomi sebagai dasar manajemen yang baik pada usaha olahan buahbuahan lokal dan produk kerajinan ibu-ibu rumah tangga juga diberikan oleh mahasiswa peserta KKNPPM terhadap mitra. Analisis ekonomi secara sederhana dimulai dengan penjelasan dan simulasi tentang rencana bisnis. Kasali (2010), mengatakan gagalnya calon pengusaha atau pengusaha di awal usaha mereka adalah akibat tidak mampu merancang perencanaan bisnis (business plan) yang baik.

Materi pengemasan dan pelabelan merupakan materi lanjutan pada pelatihan dan pendampingan yang dilakukan oleh mahasiswa peserta KKN-PPM Untan terhadap ibu-ibu rumah tangga dalam menjalankan usaha olahan buah-buahan lokal serta produk kerajinan. Menurut Cenadi (2000), kemasan merupakan "pemicu" karena fungsinya langsung berhadapan dengan konsumen. Dengan demikian, kemasan harus dapat memberikan impresi spontan yang mempengaruhi tindakan positif konsumen di tempat penjual. Begitu pentingnya kemasan dan label suatu produk dalam pemasaran, maka pada pelaksanaan program ini, materi ini diintroduksikan kepada ibu-ibu rumah tangga dengan penjelasan pentingnya pengemasan dan pelabelan suatu produk, dilanjutkan dengan demonstrasi.

Selain pelatihan dan pendampingan terhadap pemanfaatan buah-buahan lokal serta limbahnya sebagai target dalam program utama, mahasiswa juga melakukan kegiatan-kegiatan sebagai program tambahan sehingga bisa meningkatkan rasa empati mahasiswa terhadap masyarakat perdesaan, seperti ikut serta gotong royong, membantu meningkatkan kemampuan baca tulis masyarakat yang masih buta huruf dan membantu anak-anak SD dan SMP dalam belajar.

\subsection{Monitoring dan Evaluasi}

Kegiatan monitoring dan evaluasi dilakukan oleh DPL 1x/minggu. Monitoring dan evaluasi ini sekaligus kegiatan pendampingan DPL terhadap mahasiswa peserta KKN-PPM dalam melaksanakan programprogram yang telah disusun sebelumnya.

Hasil evaluasi yang dilakukan secara berkala menunjukkan bahwa pelatihan dan pendampingan yang telah dilakukan mahasiswa terhadap ibu-ibu rumah tangga sebagai mitra menunjukkan hasil yang optimal, hal ini berdasarkan tanya jawab antara DPL dengan 30 (tigapuluh) orang ibu-ibu rumah tangga peserta pelatihan dan pendampingan yang dipilih secara acak melalui kuesioner yang akan menjadi indikator pemahaman, sikap dan kemampuan sebagai hasil dari partisipasi mitra dalam proses pelaksanaan program KKN-PPM Untan tahun 2018. Tabel berikut merupakan rata-rata dari hasil jawaban sejumlah pertanyaan yang diajukan dalam kuesioner yang telah disusun berdasarkan indikator yang harus dicapai dalam proses pelatihan dan pendampingan yang dilakukan oleh mahasiswa KKN-PPM Untan di Dusun Lingga Dalam. 
Tabel 2. Pemahaman, Sikap dan Kemampuan Ibu-ibu Rumah Tangga terhadap Materi Pelatihan dan Pendampingan Program KKN-PPM Untan.

\begin{tabular}{lll}
\hline Indikator & \multicolumn{3}{c}{ Skor $^{*}$} \\
\cline { 2 - 3 } & $\mathbf{1} \quad \mathbf{2} \quad \mathbf{3} \quad \mathbf{4}$ \\
\cline { 2 - 3 } & \multicolumn{3}{c}{ Jawaban $(\%)$} & \\
\hline
\end{tabular}

- $\quad$ Sikap mitra terhadap $\begin{array}{lllll}0 & 0 & 20 & 80\end{array}$ program KKN-PPM

- Sikap mitra terhadap $\begin{array}{lllll}0 & 0 & 80 & 20\end{array}$ rencana usaha olahan buahbuahan lokal dan produk kerajinan yang berorientasi bisnis / komersial

- Pemahaman mitra terhadap $\begin{array}{lllll}0 & 0 & 70 & 30\end{array}$ materi pelatihan produksi olahan pisang, rambutan dan kerajinan dari pelepah pisang

- Pemahaman mitra terhadap $\begin{array}{lllll}0 & 10 & 80 & 10\end{array}$ materi analisis ekonomi sederhana, pengemasan dan pelabelan

- Kemampuan mitra dalam $\begin{array}{lllll}0 & 0 & 70 & 30\end{array}$ menerapkan teknologi pemanfaatan buah-buahan lokal dan limbah/pelepah pisang

- Kemampuan mitra dalam $\begin{array}{lllll}0 & 20 & 70 & 10\end{array}$ menerapkan materi analisis ekonomi sederhana, pengemasan dan pelabelan

Sumber : : Analisis Data Primer, 2018

Keterangan skor* :

$1=$ tidak baik/tidak paham/tidak mampu

$2=$ kurang baik/kurang paham/kurang mampu

$3=$ cukup baik/cukup paham/cukup mampu

4= sangat baik/sangat paham/sangat mampu

Tabel 2 menunjukkan bahwa sikap mitra terhadap program KKN-PPM dan rencana usaha olahan buahbuahan lokal dan produk kerajinan sangat baik dan cukup baik, dengan ditunjukkan sebesar $80 \%$ peserta mitra atau 24 orang ibu rumah tangga yang diwawancarai menyambut sangat baik, sedangkan $20 \%$ (6 orang ibu rumah tangga) menyambut baik terhadap pelaksanaan program. Pada saat ditanyakan sikap mereka tentang kemungkinan usaha pemanfaatan buah-buahan lokal dan pelepah pisang menjadi usaha berorientasi bisnis/komersial, sebanyak 24 orang ibu rumah tangga $(80 \%)$ menjawab cukup baik dan 6 orang (20\%) menjawab sangat baik. Indikasi jawaban tersebut menunjukkan bahwa ibu-ibu rumah tangga cukup optimis bahwa usaha ini akan berhasil sehingga sangat antusias dalam merencanakan usaha olahan tersebut. Hal ini menjadi modal dasar dalam proses pelatihan dan pendampingan terhadap mitra dalam memanfaatkan buah-buhan lokal menjadi berbagai produk olahan dan produk kerajinan dari pelepah pisang. Dengan sikap menerima baik dan menyukai suatu rencana terlebih dahulu, dimungkinkan pemahaman dan kemampuan mitra terhadap seluruh materi menjadi lebih optimal. Pemahaman dan kemampuan ibu-ibu rumah tangga sebagai mitra terhadap materi-materi yang diintroduksikan dalam pelatihan dan pendampingan pada program KKN-PPM juga menunjukkan persentasi yang "cukup - sangat paham/mampu".

Hasil pendampingan, monitoring dan evaluasi juga menunjukkan adanya perubahan pola pikir ibu-ibu rumah tangga tentang pemanfaatan buahbuahan lokal dan pelepah pisang. Buah-buahan lokal yang selama ini hampir tidak memiliki nilai, dengan proses pelatihan dan pendampingan para ibu peserta sangat berharap ke depan pemanfaatan ini menjadi andalan dalam meningkatkan pendapatan dan kesejahteraan keluarga.

\section{SIMPULAN DAN SARAN}

\subsection{Simpulan}

Simpulan dari kegiatan pengabdian kepada masyarakat program KKN-PPM dengan mitra ibu-ibu rumah tangga di Dusun Lingga Dalam di bawah koordinasi Kepala Desa Lingga Kecamatan Sungai Ambawang Kabupaten Kubu Raya-Kalimantan Barat adalah: 1) Terjadi kerjasama yang sinergi antara masyarakat pedesaan dan Universitas Tanjungpura, 2) Meningkatnya daya empati mahasiswa terhadap kehidupan ekonomi perdesaan, terutama ekonomi lemah, 3) meningkatnya pengetahuan dan ketrampilan ibu-ibu rumah tangga dalam memanfaatkan buahbuahan lokal dan pelepah pisang menjadi berbagai olahan dan produk kerajinan sehingga nilai tambahnya meningkat.

\subsection{Saran}

Mengingat nilai manfaat teknologi yang diintroduksikan bagi ibu-ibu rumah tangga di Dusun Lingga Dalam sangat tinggi, maka pada tahap selanjutnya sangat diperlukan pendampingan lebih intensif, terutama dalam pemasaran produk olahan tersebut. Selain itu, penerapan teknologi tersebut juga dapat diperluas ke masyarakat di sekitarnya di Desa Lingga, sehingga menjadi kegiatan andalan dalam meningkatkan pendapatan rumah tangga.

\section{UCAPAN TERIMA KASIH}

Terimakasih kepada Direktorat Riset dan Pengabdian Masyarakat Ditjen Penguatan Riset dan Pengembangan Kementerian Riset, Teknologi dan Pendidikan Tinggi dan Rektor Universitas Tanjungpura melalui Ketua LPPKM UNTAN, yang telah memfasilitasi dan mendanai pengabdian pada masyarakat ini. Penulis juga mengucapkan terimakasih yang sebesar-besarnya kepada Kepala Desa Lingga, dan tokoh-tokoh masyarakat desa serta ibu-ibu rumah tangga dan semua pihak yang mendukung dalam kegiatan ini. 


\section{DAFTAR PUSTAKA}

Anonim, 2012. Tim Nasional Percepatan Penanggulangan Kemiskinan (TNP2K) Provinsi Kalimantan Barat.

Anonim, 2016. Profil Desa Lingga. Kantor Desa Lingga. Kecamatan Sungai Ambawang Kabupaten Kubu Raya. Kalimantan Barat.

BPS, 2014. Kecamatan Sungai Ambawang dalam Angka 2014. Badan Pusat Statistik Kabupaten Kubu Raya.

Cenadi, C. S. 2000. Peranan Desain Kemasan dalam Dunia Pemasaran. Jurnal Nirmana Vol. 2. No.1 Edis i Januari 2000: 92-103

Dewi, Y.S.K. dan Komariyati. 2012. Peta Kerawanan Pangan Wilayah Perbatasan Kabupaten Bengkayang-Serawak. Laporan Penelitian Kerjasama Lembaga Penelitian UNTAN dan Badan Perbatasan Daerah Kalimantan Barat.

Dewi, Y.S.K. 2015. Pemberdayaan Petani Rawan Pangan Melalui Kawasan Ekonomi Masyarakat (KEM) Desa Lingga Kabupaten Kubu Raya Kalimantan Barat. Laporan Kajian. FW Equator

Fauziati, 2008. Pemanfaatan dan Prospek Pelepah Batang Pisang Kepok Sebagai Bahan Baku Mebel. Jurnal Riset Teknologi Industri Volume 2 No. 4. Edisi Desember 2008

Kasali R. 2010. Wirausaha Muda Mandiri (Independent Young Entrepreneur). Gramedia Pustaka Utama. Jakarta

Pramulya, M. 2016. IbM Kelompok Tani Desa Lingga Melalui Olahan Pisang dan Limbahnya. Laporan Pelaksanaan. UNTAN

Prabawati, S., Suyanti dan Setyabudi, D.A,. 2008. Teknologi Pascapanen dan Teknik Pengolahan Buah Pisang. Balai Besar Penelitian dan Pengembangan Pascapanen Pertanian.

Putri, T.K., dkk. 2015. Pemanfaatan Jenis-Jenis Pisang (Banana dan Plantain) Lokal Jawa Barat Berbasis Produk Sale dan Tepung. Jurnal Kultivasi Vol. 14(2) Oktober 2015

Widyawati, N., Sunaryanto, L.T., dan Murdono, D. 2016. Optimalisasi Pemanfaatan Sumber Daya Hayati Rambutan Kelengkeng Desa Karangrejo, Borobudur Kabupaten Magelang Melalui Okulasi. Jurnal Agric Vol. 28 No. 1\&No. 2. Edisi Juli \& Desember 2016 : 55-68 